\title{
Extensive survey of the Endangered Coquerel's sifaka Propithecus coquereli
}

\section{Jordi Salmona ${ }^{1, *}$, Fabien Jan' ${ }^{1}$, Emmanuel Rasolondraibe ${ }^{2}$, Aubin Besolo ${ }^{2}$, Dhurham Saïd Ousseni ${ }^{2}$, Angelika Beck ${ }^{1}$, Radavison Zaranaina ${ }^{2}$, Heriniaina Rakotoarisoa ${ }^{2}$, Clément Joseph Rabarivola ${ }^{2}$, Lounès Chikhi ${ }^{1,3,4}$}

\author{
${ }^{1}$ Instituto Gulbenkian de Ciência, Rua da Quinta Grande, 6, 2780-156 Oeiras, Portugal \\ ${ }^{2}$ Faculté des Sciences, Université de Mahajanga, BP 652401 Mahajanga, Madagascar \\ ${ }^{3}$ CNRS, Université Paul Sabatier, ENFA; UMR 5174 EDB (Laboratoire Evolution \& Diversité Biologique), 118 route de Narbonne, \\ 31062 Toulouse, France \\ ${ }^{4}$ Université de Toulouse; UMR 5174 EDB, 31062 Toulouse, France
}

\begin{abstract}
Coquerel's sifaka Propithecus coquereli has a large but highly fragmented distribution. Despite its Endangered (EN) IUCN conservation status, uncertainties persist regarding its actual distribution and its presence in forests that are thought to be part of its distribution range. We provide here the first extensive population surveys of Coquerel's sifaka across a large number of forest fragments neighboring 27 sites of its known and expected distribution range in northwestern Madagascar, including 12 previously visited sites. During our diurnal surveys carried out in the dry seasons from 2009 to 2011 we observed the species in 26 of the 27 visited sites. Combining our results with previously published data, we propose a refined update of the species' distribution range and identify areas to be surveyed. We also recorded the support tree species on which sifakas were observed, and note that, surprisingly, P. coquereli was frequently seen around villages and in areas dominated by introduced tree species. Although the species was present at almost all the visited sites of its highly fragmented distribution range, it remains unclear how viable the populations of a significant proportion of these sites actually are. Due to political instability and high rates of deforestation, large-scale conservation actions are urgently needed. We thus (1) discuss the outline of a possible metapopulation conservation action plan for $P$. coquereli and (2) identify priority sites and actions.
\end{abstract}

KEY WORDS: Survey $\cdot$ Distribution range $\cdot$ Propithecus coquereli $\cdot$ Sifaka $\cdot$ Lemur $\cdot$ Madagascar Resale or republication not permitted without written consent of the publisher

\section{INTRODUCTION}

In the last couple of decades our knowledge of the distribution and number of lemur species across Madagascar has increased (Mittermeier et al. 2008, 2010, Schwitzer et al. 2013). However, there is still no baseline data (i.e. distribution, abundance) available for many regions and species, including recently discovered species (Weisrock et al. 2010). For species that have been known for decades but are distributed over a wide area or live in little-studied regions, data may be similarly deficient (Ravaloharimanitra et al. 2011, Rakotonirina et al. 2013, Salmona et al. in press).
This is the case for Coquerel's sifaka Propithecus coquereli, which was historically reported to inhabit the Sofia region between the Betsiboka and Maevarano watersheds (Mittermeier et al. 2010, Wilmé et al. 2012; Fig. 1). The distributions typically reported for many lemurs, including $P$. coquereli, are based on a relatively limited number of actual observations in the field. Despite the Endangered (EN) status (IUCN 2013, Schwitzer et al. 2013) of the Coquerel's sifaka and its possible role as an umbrella species for the conservation of other species, regions or habitats, no extensive survey of its whole distribution range has ever been conducted. The last meeting of the IUCN Species Survival Commission (SSC) for lemur Red 


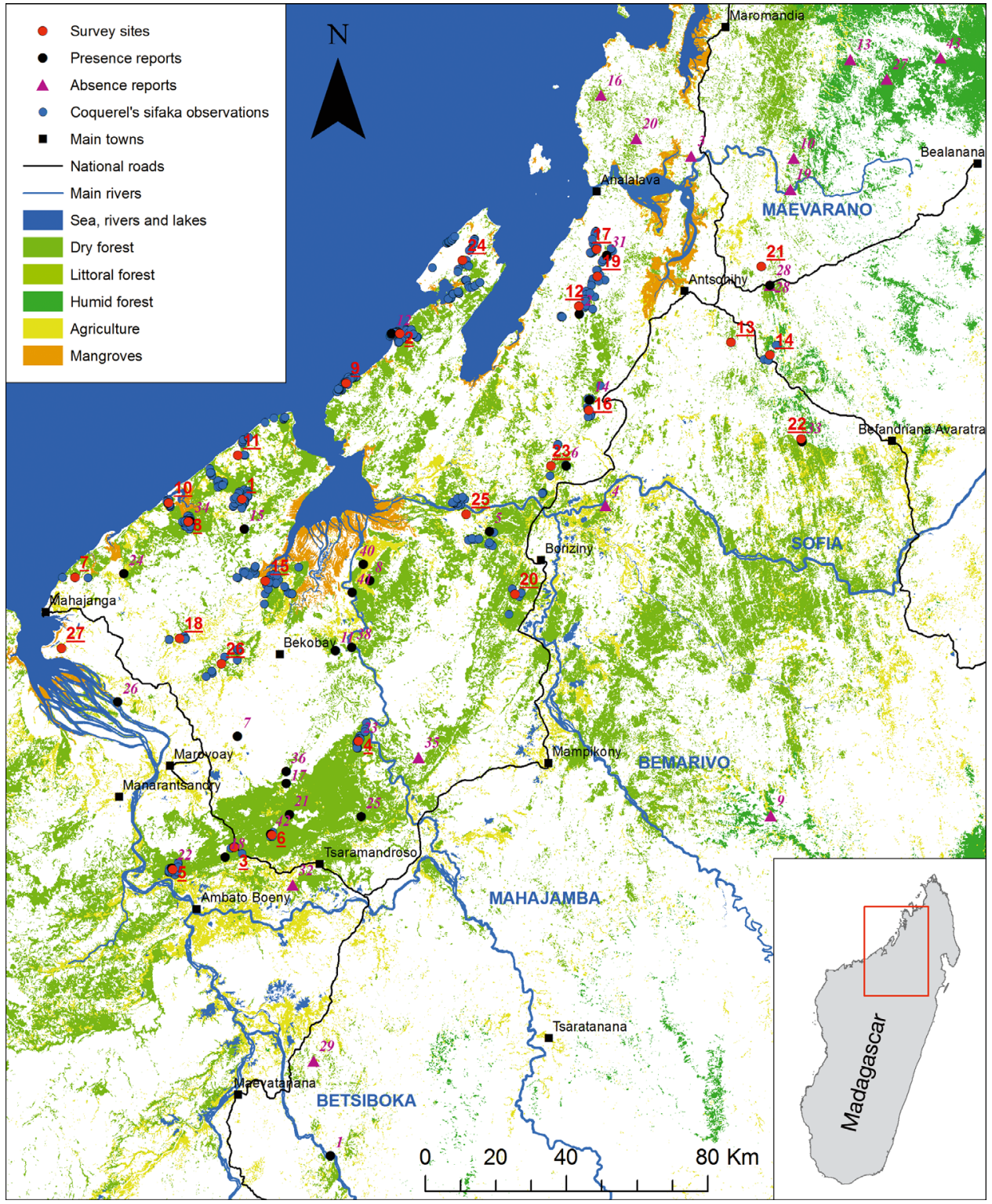

Fig. 1. Surveyed sites and Propithecus coquereli presence/absence bibliographic report locations in NW Madagascar. Purple italic numbers refer to reports and correspond to location numbers in Table 1 ; red underlined numbers refer to surveyed sites or forests and correspond to the location numbers in Table 2. Vegetation areas are taken from Moat \& Smith (2007)

List reassessment in 2012 led to the proposal of only 3 conservation priority sites within the known distribution range of P. coquereli (Schwitzer et al. 2013, 2014). Nevertheless, a species with such a large and highly fragmented distribution range should be conserved using a metapopulation management strategy, as suggested for its sister species $P$. coronatus (King et al. 2012). To develop this type of approach, and identify priority areas suitable for local management/conservation projects, a good knowledge of the existing populations and of their distribution range is required. In this context, and considering the rapid forest loss and fragmentation across western Madagascar (MEFT, USAID, CI 2009), we conducted this urgently needed survey.

\section{MATERIALS AND METHODS}

We surveyed 26 sites in northwestern Madagascar, including 12 that had previously been surveyed (Tables 1 \& 2, Fig. 1). Sites were chosen based on (1) previous bibliographic presence reports of Propithecus coquereli (Table 1), (2) vegetation maps and atlas 
Table 1. Bibliographic review of Propithecus coquereli reports. Site numbers refer to the presence or absence of the species at the (purple italic) location numbers in Fig. 1

\begin{tabular}{|c|c|c|c|c|c|c|c|}
\hline Site & $\begin{array}{l}\text { Site } \\
\text { no. }\end{array}$ & $\begin{array}{l}\text { GPS } \\
\left({ }^{\circ} \mathrm{S}\right)\end{array}$ & $\begin{array}{l}\text { GPS } \\
\left({ }^{\circ} \mathrm{E}\right)\end{array}$ & Year & Period & $\begin{array}{c}\text { Presence/ } \\
\text { Absence }\end{array}$ & Reference \\
\hline Ambalanjanakomby & 1 & 17.10 & 47.08 & 2010 & Oct & Presence & Rakotonirina et al. (in press) \\
\hline Ambarijeby & 2 & 14.94 & 47.71 & 2004 & May to Jun & Presence & Olivieri et al. (2005) \\
\hline Ambendrana & 3 & 14.53 & 48.00 & 2003 & Jul to Sep & Absence & Randriatahina \& Rabarivola (2004) \\
\hline Ambodimadiro, Sofia ${ }^{\mathrm{a}}$ & 4 & 15.43 & 47.79 & 2004 & & Absence & G. Rakotoarisoa (pers. comm.) \\
\hline Ambodimadiro, Maevarano & 43 & 14.27 & 48.65 & 2003 & July to Sep & Absence & Randriatahina \& Rabarivola (2004) \\
\hline Ambodimahabibo & 5 & 15.50 & 47.48 & 2004 & Jul to Aug & Presence & Olivieri et al. (2005) \\
\hline Ambongabe & 6 & 15.33 & 47.68 & 2003 & Jul to Aug & Presence & Olivieri et al. (2005) \\
\hline Ampijoroa, Ankarafantsika & 7 & $\begin{array}{l}16.03 \\
16.03 \\
16.03 \\
16.03 \\
16.03 \\
16.03 \\
16.03 \\
16.03 \\
16.30\end{array}$ & $\begin{array}{l}46.82 \\
46.82 \\
46.82 \\
46.82 \\
46.82 \\
46.82 \\
46.82 \\
46.82 \\
46.82\end{array}$ & $\begin{array}{c}1962 \\
1974 \\
1978 \\
1981 \\
1985 \& 1986 \\
2000 \\
2007 \text { to } 2008 \\
2009 \\
1969 \text { to } 1974\end{array}$ & $\begin{array}{l}\text { Dec \& Jan } \\
\quad \text { Sep }\end{array}$ & $\begin{array}{l}\text { Presence } \\
\text { Presence } \\
\text { Presence } \\
\text { Presence } \\
\text { Presence } \\
\text { Presence } \\
\text { Presence } \\
\text { Presence } \\
\text { Presence }\end{array}$ & $\begin{array}{l}\text { Petter (1962) } \\
\text { Richard (1974) } \\
\text { Richard (1978b) } \\
\text { Albignac (1981) } \\
\text { Ganzhorn (1988) } \\
\text { Radespiel \& Raveloson (2001) } \\
\text { McGoogan (2011) } \\
\text { Kun-Rodrigues et al. (2014) } \\
\text { Sussman (1977) }\end{array}$ \\
\hline Analalabe $^{\mathrm{a}}$ & 8 & 15.63 & 47.17 & 2004 & & Presence & G. Rakotoarisoa (pers. comm.) \\
\hline Analamaitso, Tampoketsa BB & 9 & 16.22 & 48.23 & 1999 & Jul & Absence & Ralison (2000) \\
\hline Andakalaka $^{\mathrm{a}}$ & 26 & 16.95 & 46.50 & 2009 & & Presence & S. Wohlhauser (pers. comm.) \\
\hline Andranobe & 10 & 14.54 & 48.27 & 2003 & Jul to Sept & Absence & Randriatahina \& Rabarivola (2004) \\
\hline Andranolava, Lac & 11 & 15.81 & 47.08 & 1997 & May to Jul & Presence & Wilmé et al. (2006) \\
\hline Anjajavy, Ankidivy & 12 & 15.00 & 47.22 & 2004 & Jul & Presence & Wilmé et al. (2006) \\
\hline Anjajavy, Hôtel \& S & & 15.00 & 47.23 & 2004 & Jul & Presence & Wilmé et al. (2006) \\
\hline Anjajavy, near Grotte Unique & & 15.05 & 47.24 & 2004 & Jul & Presence & Wilmé et al. (2006) \\
\hline Anjavidimarina & 13 & 14.28 & 48.41 & 2003 & Jul to Sep & Absence & Randriatahina \& Rabarivola (2004) \\
\hline Anjiamangirana I & 14 & 15.16 & 47.74 & 2004 & Sep to Oct & Presence & Olivieri et al. (2005) \\
\hline Anjohibe, Grottes d' & 15 & 15.50 & 46.83 & 1962 & Oct & Presence & Wilmé et al. (2006) \\
\hline Ankarafa & 16 & $\begin{array}{l}14.38 \\
14.38\end{array}$ & $\begin{array}{l}47.76 \\
47.76\end{array}$ & $\begin{array}{l}2004 \\
2003\end{array}$ & $\begin{array}{l}\text { Oct } \\
\text { Jul to Sept }\end{array}$ & $\begin{array}{l}\text { Absence } \\
\text { Absence }\end{array}$ & $\begin{array}{l}\text { Olivieri et al. (2005) } \\
\text { Randriatahina \& Rabarivola (2004) }\end{array}$ \\
\hline Ankarafantsika & 17 & 16.15 & 46.95 & 1959 & Oct & Presence & Wilmé et al. (2006) \\
\hline Ankarokaroka, Ankarafantsika & 18 & $\begin{array}{l}16.34 \\
16.34\end{array}$ & $\begin{array}{l}46.79 \\
46.79\end{array}$ & $\begin{array}{l}1997 \\
2000\end{array}$ & $\begin{array}{l}\text { Feb } \\
\text { Sep }\end{array}$ & $\begin{array}{l}\text { Presence } \\
\text { Presence }\end{array}$ & $\begin{array}{l}\text { Schmid \& Rasoloarison (2002) } \\
\text { Radespiel \& Raveloson (2001) }\end{array}$ \\
\hline Ankiabe & 19 & 14.61 & 48.26 & 2003 & July to Sep & Absence & Randriatahina \& Rabarivola (2004) \\
\hline Antsakoamamy & 20 & 14.49 & 47.85 & 2003 & Jul to Sep & Absence & Randriatahina \& Rabarivola (2004) \\
\hline Antsiloky, Ankarafantsika & 21 & 16.23 & 46.96 & 1997 & Feb & Presence & Schmid \& Rasoloarison (2002) \\
\hline Bealana, Ankarafantsika & 22 & 16.37 & 46.65 & 2009 & Aug to Sep & Presence & Kun-Rodrigues et al. (2014) \\
\hline Beronono, Ankarafantsika & 23 & 16.04 & 47.14 & 2009 & Aug & Presence & Kun-Rodrigues et al. (2014) \\
\hline Betsaka & 24 & 15.62 & 46.52 & 1891 & Jan & Presence & Wilmé et al. (2006) \\
\hline Bevazaha, Ankarafantsika & 25 & $\begin{array}{l}16.23 \\
16.23\end{array}$ & $\begin{array}{l}47.15 \\
47.15\end{array}$ & $\begin{array}{l}1950 \\
2000\end{array}$ & $\begin{array}{l}\text { Feb } \\
\text { Sept }\end{array}$ & $\begin{array}{l}\text { Presence } \\
\text { Presence }\end{array}$ & $\begin{array}{l}\text { Wilmé et al. (2006) } \\
\text { Radespiel \& Raveloson (2001) }\end{array}$ \\
\hline Bongomarina & 27 & 14.33 & 48.51 & 2003 & July to Sept & Absence & Randriatahina \& Rabarivola (2004) \\
\hline Bora & 28 & $\begin{array}{l}14.86 \\
14.86 \\
14.87\end{array}$ & $\begin{array}{l}48.21 \\
48.21 \\
48.20\end{array}$ & $\begin{array}{l}2004 \\
2005 \\
2002\end{array}$ & $\begin{array}{l}\text { Jun } \\
\text { Dec } \\
\text { May to Jun }\end{array}$ & $\begin{array}{l}\text { Presence } \\
\text { Absence } \\
\text { Presence }\end{array}$ & $\begin{array}{l}\text { Olivieri et al. (2005) } \\
\text { Koenig \& Zavasoa (2006) } \\
\text { Randrianambinina et al. (2003) }\end{array}$ \\
\hline Le Croisement & 29 & 16.86 & 47.03 & 2003 & May & Absence & Olivieri et al. (2005) \\
\hline Mahajamba complex & 12 & 15.03 & 47.27 & 2007 & July & Presence & Ravoahangy et al. (2008) \\
\hline Mahatsinjo & 31 & 14.79 & 47.78 & 2004 & Sep & Presence & Olivieri et al. (2005) \\
\hline Mangatelo & 32 & 16.41 & 46.97 & 2003 & May to Jun & Absence & Olivieri et al. (2005) \\
\hline Marasakoa & 33 & 15.26 & 48.30 & 2004 & Jul & Presence & Olivieri et al. (2005) \\
\hline Mariarano & 34 & $\begin{array}{l}15.48 \\
15.48\end{array}$ & $\begin{array}{l}46.69 \\
46.69\end{array}$ & $\begin{array}{l}2003 \\
2006\end{array}$ & $\begin{array}{l}\text { Jul } \\
\text { Nov }\end{array}$ & $\begin{array}{l}\text { Presence } \\
\text { Presence }\end{array}$ & $\begin{array}{l}\text { Olivieri et al. (2005) } \\
\text { Rambinintsoa et al. (2006) }\end{array}$ \\
\hline Maroakata & 35 & 16.08 & 47.30 & 2003 & Aug to Sep & Absence & Olivieri et al. (2005) \\
\hline Ste Marie & 36 & 16.12 & 46.95 & 2000 & Sep & Presence & Radespiel \& Raveloson (2001) \\
\hline Tananvaovao & 34 & 15.47 & 46.67 & 2003 & Jul to Aug & Presence & Olivieri et al. (2005) \\
\hline Tsiaramaso & 38 & 15.80 & 47.12 & 2003 & Oct & Presence & Olivieri et al. (2005) \\
\hline Tsimaloto, Ankarafantsika & 25 & 16.23 & 47.14 & 1997 & Feb & Presence & Schmid \& Rasoloarison (2002) \\
\hline Tsinjoarivo $^{\mathrm{a}}$ & 40 & 15.59 & 47.15 & 2004 & & Presence & G. Rakotoarisoa (pers. comm.) \\
\hline Tsinjomitondraka & 41 & 15.66 & 47.12 & 2004 & Aug & Presence & Olivieri et al. (2005) \\
\hline Vava'ny Marovoay & 42 & 16.28 & 46.91 & 2009 & Aug & Presence & Kun-Rodrigues et al. (2014) \\
\hline
\end{tabular}




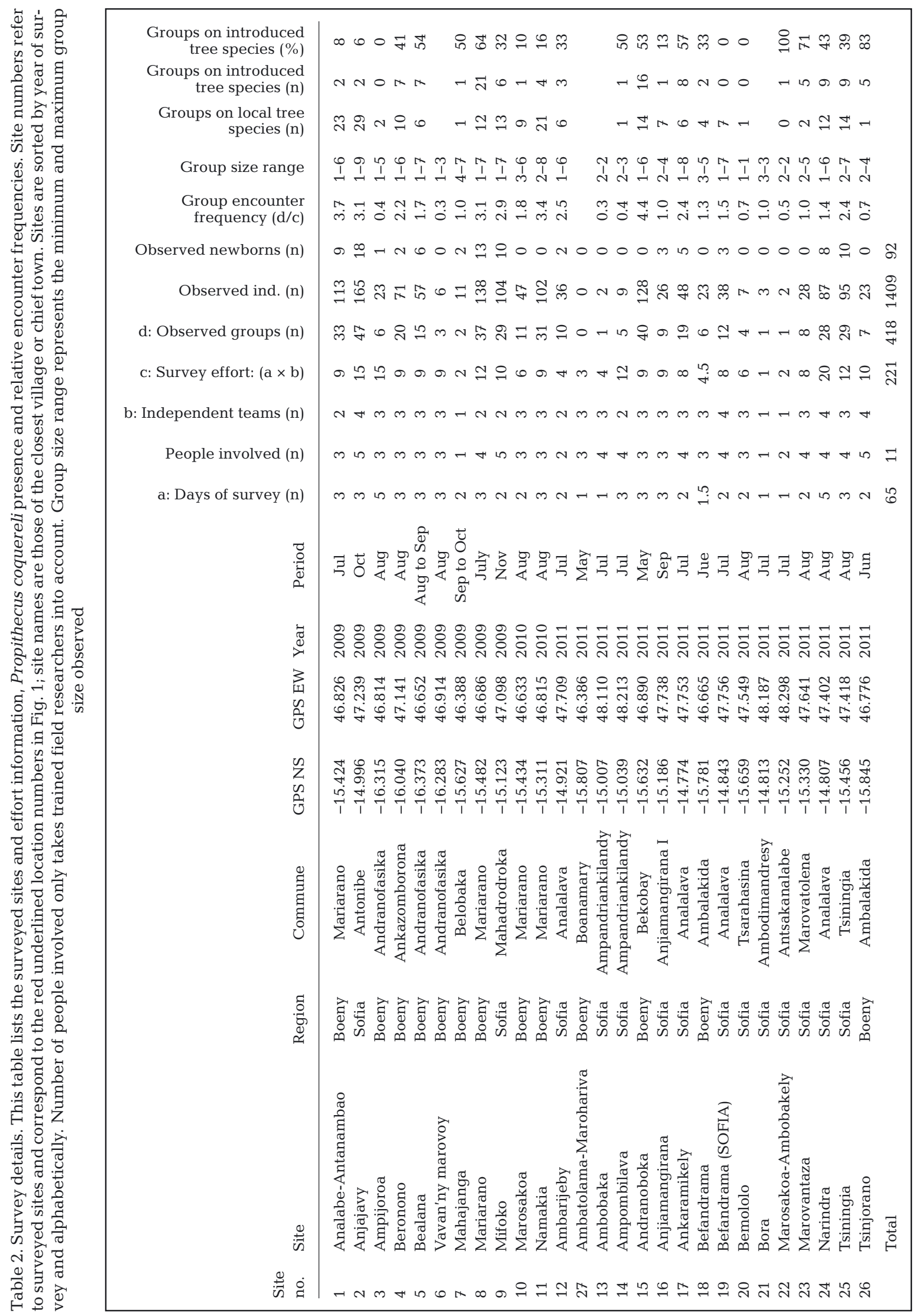


(Moat \& Smith 2007, and (3) available satellite images (Google Earth ${ }^{\circledR}$; Landsat). The principal aim of our presence in the field was to collect fecal samples for future genetic analyses from as many forest fragments as possible in the full previously known distribution range of Coquerel's sifaka. Sites were surveyed by several 2-3 member teams composed of 1-2 trained field researchers and a local guide, during 2 to 6 mo periods of the dry season each year between July 2009 and August 2011 (Table 2). Diurnal surveys of forest fragments, forest corridors, riparian forests, and mango- and tamarind-dominated tree groves surrounding villages and cultivated areas were conducted on and/or off existing trails, with observers walking slowly $\left(\sim 2 \mathrm{~km} \mathrm{~h}^{-1}\right)$ looking and listening for lemur presence. Teams spread out in a star-like pattern (to avoid overlapping of several teams) every morning with the objective of visiting an area previously identified on printed maps or satellites images. Guides (usually local farmers) were allocated to the different teams depending on their self-reported knowledge of the respective areas. During the survey each team could use trails or not and follow the guide's suggestions (in some areas the guides knew exactly where the sifaka groups would be) as long as the team stayed in the predefined area of survey.

For each observation of Coquerel's sifaka, group size, presence of newborns, support tree genus or species and geographic position (with Garmin ${ }^{\circledR}$ Etrex-H GPS, allowing a maximum error of $5 \mathrm{~m}$ and using the WGS84 referencing system) were recorded. When a group was spotted, the team usually spent 20 to 45 min collecting fresh fecal samples from individuals. Consequently, the survey was not adapted for abundance estimation (i.e. in forests with high encounter frequencies, a team could spend almost all of its time sampling feces, while in sites with low encounter frequencies we sometimes surveyed a large area without spotting any lemurs). Since our principal aim was to identify and sample existing populations, no attempt was made to use distancesampling methods (except in Ankarafantsika, see Kun-Rodrigues et al. 2014), which are significantly more time consuming. However, we calculated relative encounter frequency per site, dividing the number of observations by the survey effort (number of survey days $\times$ number of teams involved). These easily calculated numbers give a rough idea of the relative importance of the population of each visited site. Nevertheless, they are not as accurate as (and cannot be compared with) encounter rates calculated from more standardized surveys, or of density estimated from line transect distance sampling surveys.

\section{RESULTS}

We observed Coquerel's sifakas at 26 sites (Table 2, Fig. 1) out of a total of 27, which included 15 newly visited forests. The only site with no observation of Propithecus coquereli was AmbatolamaMarohariva (Site 27) close to the town of Mahajanga. In addition, we report observations of $P$. coquerel at 4 additional sites (G. Rakotoarisoa and S. Wohlhauser pers. comm., Table 1), thus extending to 19 the number of new survey sites. The highest encounter frequencies (in group per day) were recorded for Mifoko, Mariarano, Analabe, Andranoboka and Anjajavy (Table 2, Fig. 1). Of the 27 ( 44\%) localities 12 had relatively low encounter frequency, with values $\leq 1$ (i.e. survey teams spotted only one or less sifaka group per day of survey on average; Table 1). The proportion of groups encountered on introduced tree species was high and comprised more than half of the observation in some sites, such as Mariarano (Table 2).

\section{DISCUSSION}

\section{Distribution}

Altogether, our results confirm the presence of Propithecus coquereli in its previously described distribution range, between the Betsiboka and Maevarano watersheds (Wilmé et al. 2006, 2012, Mittermeier et al. 2010; Fig. 1). Despite 78 d of survey over 3 dry seasons of field work, we did not have enough time to visit the areas between the Sofia and Bemarivo rivers, where the species has twice been reported to be absent (Ralison 2000, Gilbert Rakotoarisoa pers. comm.; Table 1). Similarly, the southern part of the inter-river system between the Bemarivo and Betsiboka rivers, where little is known about the presence of the species, still requires surveys. In this area, a recent survey (Rakotonirina et al. in press) reported the presence of Coquerel's sifaka $\sim 90 \mathrm{~km}$ south of the previous southernmost observations, hence extending the distribution range of the species. This means that, despite the large size and relative conspicuousness of this diurnal lemur species, uncertainties remain regarding its distribution. Future research on Coquerel's sifaka distribution should focus on determining the western limits of the distribution range, especially in the western part of the 3 inter-river systems from Sofia to Betsiboka (Fig. 1).

It is still unclear why the distribution of $P$. coquereli should stop at its current northern limit (the Mae- 
varano river, Fig. 1). Indeed, most sifakas (except $P$. perrieri and $P$. tattersalli) have distributions whose northern and southern limits are contiguous with those of generic sifaka species (Wilmé et al. 2006, Mittermeier et al. 2010). The closest northern sifaka sister species (from the western sifaka clade, Mayor et al. 2004) is $P$. tattersalli, which is located in the far northeast of Madagascar. The apparent gap between the occurrence of $P$. coquereli and $P$. tattersalli requires an explanation, be it climatic, ecologic, geographic or anthropogenic (Quéméré et al. 2012). Archaeological efforts in these 'gap regions' could help us understand how the current distribution of sifakas species has been shaped in the recent past.

Despite being present in almost all surveyed localities, sifakas were rare in nearly half of them (12 out of $27 ; \sim 44 \%$ ), with survey teams spotting at most 1 sifaka group per day of survey (group encounter frequency $\leq 1$, Table 1). Moreover, in some sites located close to Mahajanga, we found that Coquerel's sifakas were still present in very small degraded and anthropogenically disturbed tree groves (Site 7) largely because they were fed and protected by hotel personnel. In another site, they had probably disappeared recently (Site 27). The increasing urbanization around Mahajanga does not provide much hope for the persistence of the species in the area.

We found a group of $P$. coquereli in a thin riparian forest north of the Bora special reserve (Site 21). This was a good sign given the alarming situation in the reserve reported by Koenig \& Zavasoa (2006) and that the last of the 3 studies conducted in the area reported the absence of sifakas (Randrianambinina et al. 2003, Olivieri et al. 2005, Koenig \& Zavasoa 2006). Nevertheless, the Bora special reserve was not extensively surveyed during our study, and the only sifaka group observed was encountered after more than $6 \mathrm{~km}$ of survey. Moreover, the northeastern sites (Sites 13, 14, 16, 20, 21, 22, and Report 28) appear to harbor small numbers belonging to small forest fragments and probably isolated populations which may not be of viable size and are probably at a high risk of extinction in the coming decades.

A recent distance sampling survey conducted in Ankarafantsika National Park showed that despite density variation between sites (from $\sim 5$ to $~ 93$ ind. $\mathrm{km}^{-2}$ ), the population size at the Park scale may still be relatively large ( $\sim 7000$ ind.) and thus probably demographically viable (Kun-Rodrigues et al. 2014). Nevertheless, most of the surveyed forests reported here have a much smaller area and lower connectivity than the Ankarafantsika National Park (Moat \& Smith 2007). Although only a study combining den- sity estimates over a large set of sites and population size estimates (as conducted for P. coronatus; Salmona et al. in press) would enable us to assess the potential viability of each population, the encounter frequencies (Table 2) can give a rough ideas of the situation. Populations in geographically isolated sites with low and patchy forest cover and with low encounter frequencies should consequently be considered at risk.

Throughout the surveyed range, we found that Coquerel's sifakas were using both native and degraded forests (Table 2). They were frequently observed close to or in inhabited areas (within villages, in trees interspersed between groups of houses). Moreover, locals frequently mentioned that sifakas come during the dry season to feed on mango and tamarind trees. Due to the non-systematic survey methods, it is difficult to make quantitative statements about Coquerel sifaka forest and habitat uses. Although their diet is known to be diverse (Richard 1978a) and their habitat choice to be flexible (Ganzhorn 1987), it may be useful to present here different non-mutually exclusive hypotheses that could explain the observations of Coquerel's sifakas in anthropogenic areas: (1) the taboos traditionally protecting sifakas from hunting and consumption in the Sakalava ethnic group (Nicoll \& Langrand 1989, García \& Goodman 2003) are still maintained and allow sifakas to maintain high population densities close to villages; (2) high rates of deforestation (MEFT, USAID, CI 2009) reduce habitat in these areas and may force sifaka populations to use anthropogenic areas and introduced tree species; (3) food and water availability may be limited during the dry season (when our surveys took place) in both partially degraded or non-degraded forests, hence favoring seasonal movements of Coquerel's sifaka groups towards introduced tree species and anthropogenic areas.

\section{Conservation implications}

Preliminary results from this survey were used during the IUCN SSC lemur Red List reassessment meeting in Antananarivo in 2012, to help in updating the conservation status of Propithecus coquereli (Schwitzer et al. 2013, 2014). We confirm that Coquerel's sifaka is still present in most forest fragments and riparian forests of its large and highly fragmented distribution range. With such a large distribution range, the species should be used as an umbrella species for the conservation of the north- 
western forest ecosystems (Wilmé et al. 2012). In fact, over its distribution range it co-occurs with 15 lemur species including the Critically Endangered Eulemur mongoz, and 10 Endangered species (Schwitzer et al. 2013). Moreover, the protection of the forest fragments of this large area could particularly benefit 6 species endemic to that region: 3 sportive lemurs (Lepilemur edwardsii, L. otto and L. grewcockorum) and 3 mouse lemurs (Microcebus ravelobensis, $M$. bongolavensis and $M$. danfossi), which have relatively small distribution ranges (Mittermeier et al. 2010). Considering that sportive lemurs are among the easiest lemur species to catch, that there have been recent reports of its consumption, and that they do not benefit from traditional taboos protecting them, increased conservation efforts in these 3 subregion may help their conservation.

Recently, in the distribution range of $P$. coquereli, 2 site-based action plans were proposed (for the Ankarafantsika and the Anjiamangirana/Marosely sites; Schwitzer et al. 2013, 2014). Despite the fact that one of these plans covers probably the largest population of Coquerel's sifaka in its last main refugium (the Ankarafantsika National Park (KunRodrigues et al. 2014), we do believe that only a metapopulation conservation action plan (as suggested for $P$. coronatus; King et al. 2012) including all existing protected areas and covering the known distribution of $P$. coquereli would allow its efficient long-term conservation, and would benefit all the threatened biodiversity sharing its habitat. Within the distribution range of $P$. coquereli we identified 10 existing protected and/or managed areas (Table 3) which should be supported in such an action plan. Moreover we identified potential sites for conservation projects (Table 3). Efforts could focus first on maintaining and/or restoring the last northeastern populations (Sites 13, $14,16,20,21)$. Second, efforts could take advantage of the existing good coverage of protected areas in the region between the Betsiboka River, the Mahajamba Bay and the Ankarafantsika National Park. In that region the additional protection/ management of Befandrama, Tsinjorano, Andranoboka (Sites 18, 36, 15) could enable the creation of a dense regional network and benefit Coquerel's sifaka conservation. Moreover, further research is urgently required to (1) identify $P$. coquereli's presence in forests that have not been visited yet, (2) obtain accurate estimates of population structure and size, and (3) ascertain the current level of connectivity between sites and its impacts on the viability of sifaka's populations in the wild. As suggested at a national scale by Schwitzer et al. (2014), specific sitebased actions that can be carried out by conservationists, researchers, and local communities, can be less expensive than national initiatives (Schwitzer et al. 2013) and could also be an efficient solution for a such metapopulation-based action plan.

In northwestern Madagascar, savannas and bush fires are widespread during the long dry season and represent a major driver of deforestation and open habitat maintenance (Kull 2002, Jacquin et al. 2010). Habitat loss is also driven by the strong charcoal demand from the middle- and large-sized towns of the region (Schwitzer et al. 2013, Kun-Rodrigues et al. 2014) and by slash and burn agriculture (J. Salmona pers. obs.). While taboos traditionally protecting sifaka from poaching and consumption are strong in the Sakalava and Tsimihety ethnic groups

Table 3. Existing and suggested protected or managed areas in the range of Propithecus coquereli. For site and report numbers see Tables 2 and 1, respectively. MNP: Madagascar National Parks (formerly ANGAP), DGEF: Direction Régionale de l'Environnement et des Forêts, CI: Conservation International, NGO: Non Governmental Organisation, MATE: Man and the Environment. Numbers in 'Sites' column refer to numbers in Table 2 and to red numbers in Fig. 1. This table probably overlooks several community based (COBA) conservation projects managed locally

\begin{tabular}{|llc|}
\hline Area & $\begin{array}{l}\text { Project Manager/ } \\
\text { Associate }\end{array}$ & Sites \\
\hline Existing areas & & \\
Anjajavy & Anjajavy Hotel & \\
Anjiamangirana & MadagascarAye-Aye Fund & 2 \\
Ankarafantsika National Park & MNP & 16 \\
Bongolava forest corridor & DGEF-CI & $3,4,6$ \\
Bora Special Reserve & MNP & 20 \\
Mariarano & University of Mahajanga & 21 \\
Marosakoa & NGO MATE & 8 \\
Mifoko & Aqualma & 10 \\
Namakia & NGO MATE & 9 \\
Narindra peninsula & Unima & 11 \\
Potential areas & & 23 \\
Befandrama & Suggested & 18 \\
Tsinjorano & Suggested & 36 \\
Andranoboka & Suggested & 15 \\
Tsiningia & Suggested & 25 \\
Marovantaza & Suggested & 23 \\
Ambobaka-Ampombilava & Suggested & 13,14 \\
Ambarijeby-Amkaramikely & Suggested & $12,17,19$ \\
\hline
\end{tabular}


(Nicoll \& Langrand 1989, García \& Goodman 2003, Ravoahangy et al. 2008), some cases of poaching have been reported in the region (García \& Goodman 2003, Jenkins et al. 2011, Wilmé et al. 2012). During our survey, cases of leisure hunting (by people from neighboring or more distant towns) were reported in areas easily accessible from Mahajanga, as similarly reported for P. coronatus (Salmona et al. in press). Consequently, conservation efforts could focus on implementation of alternatives to (1) savanna fires in the dry season (fires are used to promote cattle grazing), (2) charcoal production and consumption, (3) slash and burn agriculture, and (4) bushmeat consumption.

Acknowledgements. We thank CAFF/CORE, the 'Direction Générale de l'Environnement et des Forêts', Madagascar National Park, the NGO 'l'Homme et l'Environnement' (in particular O. Behra, S. Blanchais) and the Aye-aye Foundation, the 'Société Verama' (in particular X. Metz), the Anjajavy Hotel (in particular C. de Foucault), the 'Société Aqualma' for giving us permission and helping us to conduct the field work. Financial support for this study was provided by the 'Fundação para a Ciência e a Tecnologia' (PTDC/BIA-BEC/ 100176/2008, PTDC/BIA_BIC/4476/2012 and SFRH/BD/ 64875/2009), the 'Institut Français de la Biodiversité' and the 'Fondation pour la Recherche sur la Biodiversité', the GDRI Madagascar, the 'Laboratoire d'Excellence' (LABEX) entitled TULIP (ANR-10-LABX-41), and the 'Instituto Gulbenkian de Ciência'. The field work was possible thanks to the continuous support of the Département de Biologie Animale et Ecologie, University of Mahajanga, the University of Antsiranana, and the Fanamby NGO (in particular S. Rajaobelina, S. Wohlhauser and V. Rasoloarison). We also thank A. Zaramody for his help and field advice. This study was conducted in agreement with the laws of the countries of Portugal, France and Madagascar. We are grateful to the editor Anna Nekaris and the reviewers for their detailed, constructive and helpful comments which greatly helped improve the quality and clarity of the manuscript.

\section{LITERATURE CITED}

Albignac R (1981) Lemurine social and territorial organization in a north-western Malagasy forest (restricted area of Ampijoroa). In: Chiarelli AB, Corruccini RS (eds) Primate behavior and sociobiology. Springer, Berlin, p 25-29

Ganzhorn JU (1987) A possible role of plantations for primate conservation in Madagascar. Am J Primatol 12: 205-215

Ganzhorn JU (1988) Food partitioning among Malagasy primates. Oecologia 75:436-450

García G, Goodman SM (2003) Hunting of protected animals in the Parc National d'Ankarafantsika, north-western Madagascar. Oryx 37:115-118

IUCN (2013) 2013 IUCN Red List of Threatened Species, Version 2013.2. www.iucnredlist.org

- Jacquin A, Sheeren D, Lacombe JP (2010) Vegetation cover degradation assessment in Madagascar savanna based on trend analysis of MODIS NDVI time series. Int J Appl Earth Obs Geoinf 12:S3-S10
Jenkins RKB, Keane A, Rakotoarivelo AR, Rakotomboavonjy $\mathrm{V}$ and others (2011) Analysis of patterns of bushmeat consumption reveals extensive exploitation of protected species in eastern Madagascar. PLoS ONE 6:e27570

King T, Rakotonirina LH, Rakotoarisoa AH, Ravaloharimanitra M, Chamberlan C (2012) Projet Tsibahaka: conserving the crowned sifaka Propithecus coronatus. Lemur News 16:32-34

Koenig P, Zavasoa A (2006) Totale disparition du Propithèque de Coquerel (Propithecus verreauxi coque- reli) du nord de la réserve spéciale Bora (Province de Mahajanga). Lemur News 11:38

Kull CA (2002) Madagascar aflame: landscape burning as peasant protest, resistance, or a resource management tool? Polit Geogr 21:927-953

Kun-Rodrigues C, Salmona J, Besolo A, Rasolondraibe E, Rabarivola C, Marques TA, Chikhi L (2014) New density estimates of a threatened sifaka species (Propithecus coquereli) in Ankarafantsika National Park. Am J Primatol 76:515-528

Mayor MI, Sommer JA, Houck ML, Zaonarivelo JR and others (2004) Specific status of Propithecus spp. Int J Primatol 25:875-900

McGoogan KC (2011) Edge effects on the behaviour and ecology of Propithecus coquereli in Northwest Madagascar. PhD thesis, University of Toronto

MEFT (Ministère de l'Environnement des Forêts et du Tourisme), USAID, CI (Conservation International) (2009) Evolution de la couverture de forêts naturelles à Madagascar 1990-2000-2005. Report by MEFT, USAID, CI. Available at http://pdf.usaid.gov/pdf_docs/pbaaa153.pdf

Mittermeier RA, Ganzhorn JU, Konstant WR, Glander K and others (2008) Lemur diversity in Madagascar. Int J Primatol 29:1607-1656

Mittermeier RA, Louis EE, Richardson M, Schwitzer C and others (2010) Lemurs of Madagascar, $3^{\text {rd }}$ edn. Conservation International, Washington, DC

Moat J, Smith P (2007)Atlas of the vegetation of Madagascar/Atlas de la végétation de Madagascar. Kew Publishing, Royal Botanic Gardens Kew, London

Nicoll ME, Langrand O (1989) Madagascar: revue de la conservation et des aires protégées. WWF-Fonds Mondial pour la Nature, Gland

Olivieri G, Craul M, Radespiel U (2005) Inventaire des lémuriens dans 15 fragments de forêt de la province de Mahajanga. Lemur News 10:11-16

Petter JJ (1962) Recherches sur l'écologie et l'éthologie des lémuriens malgaches. Mem Mus Natl Hist Nat Sér A 27: $71-84$

Quéméré E, Amelot X, Pierson J, Crouau-Roy B, Chikhi L (2012) Genetic data suggest a natural prehuman origin of open habitats in northern Madagascar and question the deforestation narrative in this region. Proc Natl Acad Sci USA 109:13028-13033

Radespiel U, Raveloson H (2001) Preliminary study on the lemur communities at three sites of dry deciduous forest in the Réserve Naturelle d'Ankarafantsika. Lemur News 6:22-24

Rakotonirina LHF, Rajaonson A, Ratolojanahary JH, Missirli JM, Fara LR, Andriamanajaranirina M, King T (2013) Southern range extensions for the critically endangered black-and-white ruffed lemur Varecia variegata and greater bamboo lemur Prolemur simus. Primate Conserv 26:49-55

Rakotonirina LH F, Rakotoarisoa AH, Rakotondrabe R, 
Razafindramanana J, Ratsimbazafy J, King T (in press) A preliminary assessment of sifaka (Propithecus spp.) distribution, chromatic variation and conservation in central Madagascar. Primate Conserv 28. Available at www. primate-sg.org/storage/pdf/PC_Rakotonirina_et_al_Sifaka _distribution.pdf

Ralison JM (2000) Observations of lemurs in the Réserve Spéciale de Tampoketsa-Analamaitso. Lemur News 5:35

Rambinintsoa A, Zaonarivelo JR, Randriamampionona R, Razafindraibe JFX, Brenneman RA, Louis EE Jr (2006) A preliminary study on resident lemur populations in the Mariarano Classified Forest. Lemur News 11:21-24

Randrianambinina B, Rasoloharijaona S, Rakotosamimanana B, Zimmermann E (2003) Inventaires des communautés lémuriennes dans la Réserve Spéciale de Bora au nordouest et la forêt domaniale de Mahilaka-Maromandia au nord de Madagascar. Lemur News 8:15-18

Randriatahina GH, Rabarivola JC (2004) Inventaire des lémuriens dans la partie nord-ouest de Madagascar et distribution d'Eulemur macaco flavifrons. Lemur News 9: 7-9

Ravaloharimanitra M, Ratolojanahary T, Rafalimandimby J, Rajaonson A and others (2011) Gathering local knowledge in Madagascar results in a major increase in the known range and number of sites for critically endangered greater bamboo lemurs (Prolemur simus). Int J Primatol 32:776-792

Ravoahangy A, Andriamaharoa HE, Randrianaina LA, Josso ATS, Raharimampionona J, Birkinshaw C (2008) Preliminary inventory of lemurs at ten priority sites for plant conservation. Lemur News 13:40-43

Richard A (1974) Intra-specific variation in the social organization and ecology of Propithecus verreauxi. Folia Primatol 22:178-207

Richard AF (1978a) Variability in the feeding behavior of a

Editorial responsibility: Anna Nekaris, Oxford, UK
Malagasy prosimian, Propithecus verreauxi: Lemuriformes. In: Montgomery E, Thorington R (eds) The ecology of arboreal folivores. Proc Nat Zool Symp 1. Smithsonian Institution Press, Washington, DC, p 519-533

Richard AF (1978b) Behavioral variation: case study of a Malagasy lemur. Associated University Presses, Cranbury

Salmona J, Rasolondraibe E, Jan F, Besolo A and others (in press) Conservation status and abundance of the crowned sifaka (Propithecus coronatus). Primate Conserv 28. Available at www.primate-sg.org/storage/pdf/PC_Salmona_ et_al_P. coronatus.pdf

Schmid J, Rasoloarison RM (2002) Lémuriens de la Réserve Naturelle Intégrale d'Ankarafantsika, Madagascar. Conserv Int Washington, DC Bull Biol Assess 23:73-82

Schwitzer C, Mittermeier RA, Davies N, Johnson S and others (2013) Lemurs of Madagascar. A strategy for their conservation 2013-2016. IUCN SSC Primate Specialist Group, Bristol Conservation and Science Foundation, and Conservation International, Bristol

Schwitzer C, Mittermeier R, Johnson S, Donati G and others (2014) Averting lemur extinctions amid Madagascar's political crisis. Science 343:842-843

> Sussman RW (1977) Distribution of the Malagasy lemurs Part 2: Lemur catta and Lemur fulvus in southern and western Madagascar. Ann NY Acad Sci 293:170-184

Weisrock DW, Rasoloarison RM, Fiorentino I, Ralison JM, Goodman SM, Kappeler PM, Yoder AD (2010) Delimiting species without nuclear monophyly in Madagascar's mouse lemurs. PLoS ONE 5:e9883

Wilmé L, Goodman SM, Ganzhorn JU (2006) Biogeographic evolution of Madagascar's microendemic biota. Science 312:1063-1065

Wilmé L, Ravokatra M, Dolch R, Schuurman D, Mathieu E, Schuetz H, Waeber PO (2012) Toponyms for centers of endemism in Madagascar. Madag Conserv Dev 7:30-40

Submitted: January 20, 2014; Accepted: June 2, 2014 Proofs received from author(s): September 11, 2014 